\title{
The Metaphysical Art of Giorgio de Chirico
}

\author{
Migraine or Epilepsy? \\ Olaf Blanke Theodor Landis \\ Department of Neurology, Geneva University Hospital, Geneva, Switzerland
}

Key Words

Epilepsy $\cdot$ Migraine $\cdot$ Neurology $\cdot$ Art $\cdot$ Temporal lobe

\begin{abstract}
It has been suggested that the great Italian painter Giorgio de Chirico (1888-1978), who developed the unique style of 'metaphysical art', suffered from migraine and used some of his morbid manifestations as a source of inspiration for his paintings. Yet, whereas many of the symptoms that de Chirico described are rare in migraine, they are frequently encountered in patients with temporal lobe epilepsy. Here we rediscuss de Chirico's symptoms critically and suggest that, if his symptoms were of neurological origin, they rather relate to temporal lobe epilepsy than migraine.
\end{abstract}

Copyright (C) 2003 S. Karger AG, Basel

\section{Introduction}

It has been suggested that the great Italian painter Giorgio de Chirico (1888-1978), who developed the unique style of 'metaphysical art' (fig. 1) and deeply influenced such surrealist artists as Max Ernst (18911976) and André Breton (1896-1966), suffered from mi-

\begin{tabular}{ll}
\hline KARGER & ( 2003 S. Karger AG, Basel \\
0014-3022/03/0504-0191\$19.50/0 \\
$\begin{array}{l}\text { Fax +4161306 12 34 } \\
\text { E-Mail karger@karger.ch } \\
\text { www.karger.com }\end{array}$ & $\begin{array}{l}\text { Accessible online at: } \\
\text { www.karger.com/ene }\end{array}$
\end{tabular}

graine and might have used some of his morbid manifestations as a source of inspiration for his paintings $[1,2]$. For this, the latter authors relied on de Chirico's extensive autopathographical writings such as The Memoirs of Giorgio de Chirico [3] and Hebdomeros [4] as well as on his paintings and drawings. Yet, many of the symptoms that de Chirico described are rare in migraine, but frequently encountered in temporal lobe epilepsy (TLE). Most importantly, the main characteristic of migraine - recurrent headache - is strikingly absent in his writings. Here we rediscuss de Chirico's symptoms critically and suggest that, if his symptoms were of neurological origin, they rather relate to TLE than migraine.

\section{Case Description: De Chirico's Symptoms}

De Chirico described his symptoms as chronic, recurrent, and stereotyped. They included motion sickness, abdominal complaints, gustatory hallucinations, as well as visual illusions and hallucinations $[1,2]$. Whereas motion sickness is a rare manifestation in TLE and in migraine, de Chirico's recurrent abdominal complaints or epigastric sensations [3] are classical features of TLE [5]. Thus, in 1906, while studying at the Fine Arts Department of the Athens Polytechnic, de Chirico remembers

Dr. Olaf Blanke

Department of Neurology, University Hospital of Geneva

24, rue Micheli-du-Crest

CH-1211 Geneva (Switzerland)

Tel. +41 22 3728347, Fax +4122 3728358, E-Mail olaf.blanke@hcuge.ch 


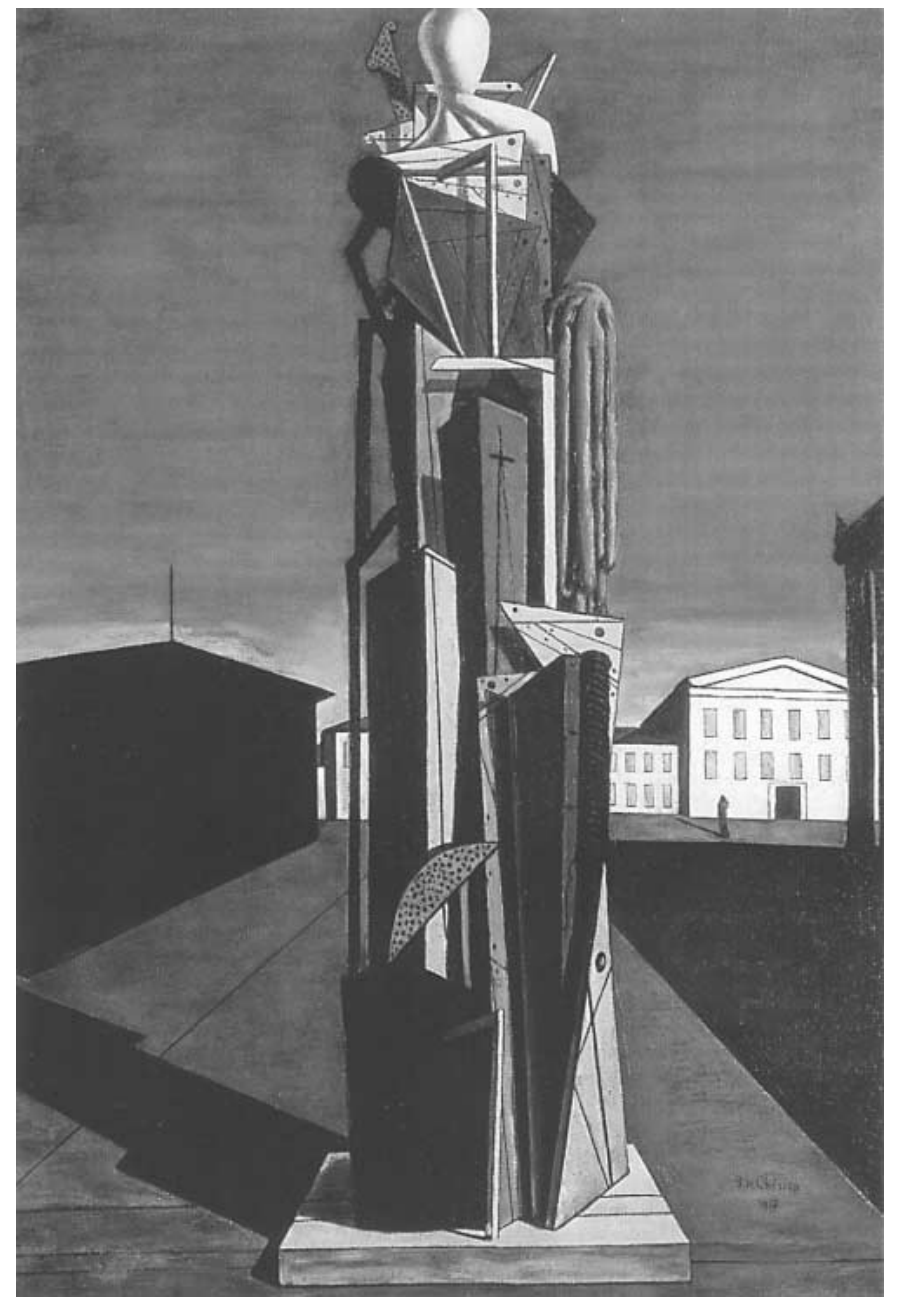

Fig. 1. The Great Metaphysician, 1917. Oil on canvas, The Museum of Modern Art, New York, USA. Copyright ProLitteris, 2003, 8033 Zürich.

that 'I was not in good health' and that 'frequent intestinal troubles and the sultry heat of the Athenian July made me feel tired, melancholic and discouraged, which certainly affected my work' [3, p. 49]. In 1910, after having moved to Munich, Milan, and Florence, de Chirico seems to have continued to suffer from recurrent epigastric sensations described as 'serious intestinal troubles [...] with no sign of improvement' [3, pp. 60-62]. Still on his move to Paris in the summer of 1911, '[he] felt very unwell. [...]' and complained of 'stomach pains' [3, p. 63], which were treated beneficially with bed rest, sedatives, poultices, and a more stable life. De Chirico's abdominal complaints were accompanied by further symptoms that are frequently encountered in patients with TLE, such as unpleasant gustatory hallucinations, anxiety and fear [2, 3]. 'In my mouth I could taste something like phenic acid. I often felt a pronounced weakness in my stomach, as though I had not eaten for two days, but when I sat down to table I had no appetite' [3, pp. 60-61]. At other times, he complained of a 'foul taste' in his mouth and although he consulted several doctors for epigastric sensations and gustatory hallucinations, his 'condition did not improve'. De Chirico also suffered from a variety of visual hallucinations, which may occur in migraine and TLE. Yet, the rapid appearance and disappearance of the visual manifestations that de Chirico described as 'a flash of darkness' or 'a great black pall flying in the wind' that appeared 'at once' [3, p. 47] (see also Podoll et al. [2]) speaks in favor of epilepsy. Although some of de Chirico's simpler visual hallucinations might resemble photisms and phosphenes, which occur in migraine, they have also been reported as epileptic manifestations. Other potentially morbid visions of de Chirico included formed visual hallucinations such as 'bubbles', 'streaks', 'lines', and 'waves' [4, p. 93] (see also Podoll et al. [2]) as well as more complex visual hallucinations such as human figures and landscapes, which are not uncommon in TLE [5, 6]. Thus, in Hebdomeros [4], de Chrico wrote: 'But at such moments it sometimes happened that the back wall opened up like a theater curtain and visions appeared, sometimes terrifying, sometimes sublime or enchanting: there would be the ocean in a storm, with hideous gnomes' or 'a spring landscape' with 'trees in blossom' or 'a woman' [4, p. 12]. These varying visual sensations were probably recurrent since de Chirico wrote that 'judging from previous experience, Hebdomeros thought that the spiritual fever which laid him low at the moment would last no longer than the preceding fevers' [4, p. 94].

Importantly, countless passages in the Memoirs [3] suggest specific personality traits that have been associated with TLE $[5,7,8]$. These include de Chirico's belief in his precognitive abilities and sense of personal destiny, his abundant writing about details of his everyday life and his varying health states, as well as paranoia and philosophical preoccupation. Thus, he stated that he foresaw the death of his father and mother [3] and detailed his precognitive experiences extensively in his Memoirs [3]. He also stated that he predicted the precise location of the shrapnel wound that Guillaume Apollinaire (1880-1918) suffered in 1916 in the famous portrait of Apollinaire that he painted in 1914 (fig. 2) [9]: 'I prophesized the head wound that Apollinaire received in the 1914-1918 war' [3, p. 66]. Another episode in 1912 further underlines de Chirico's precognitive experiences and mystical as well as philosophical interests. He was introduced to the successful 
French painter Pierre Laprade (1875-1931) who was a member of the jury of the Salon d'Automne (where de Chirico later exposed three metaphysical paintings) and visited him in his studio. 'When I entered Laprade's studio the next day I saw [...] a painting which represented a landscape identical with the one I had seen in my dream [the night before].' Yet, when de Chirico told Laprade about his special dream about the painting, the latter lightly replied to de Chirico's profound observation: 'Tiens c'est rigolo', from which de Chirico deduced that the painter Pierre Laprade did not show the same interest in the metaphysics and mystery of dreams as someone like Pythagoras or Arthur Schopenhauer [or de Chirico himself; ref. 3, p. 65]. In addition to de Chirico's major interest in moral and ethical issues, it is the clustering of these specific personality traits, which further increases the likelihood of TLE as opposed to migraine.

Importantly, the characteristic symptom of migraine, i.e. recurrent, generally unilateral headaches, is strikingly absent in de Chirico's autopathography. Headaches are only reported in two passages of the Memoirs [3]. They rather resemble muscle contraction headaches and occurred after 'exhausting and interminable visits to churches, palazzi and galleries' in Venice (see also Podoll et al. [2]). Following these visits, de Chirico 'was extremely tired, because all day I had to stand with my head raised to look at paintings and frescoes, with the result that in the evenings I had a kind of twisted neck and the back of my head was extremely painful' [3, p. 51]. Although, the location and the characteristics of migraine headaches vary and migraine may exist even without headaches, the absence of headaches speaks against the latter diagnosis.

There is no written evidence that de Chirico completely lost consciousness or suffered from tonicoclonic manifestations. Yet, he complained of recurrent periods of impaired consciousness that followed his abdominal complaints. 'I had serious intestinal troubles [...], chronic pains associated by much weakness. I could hardly climb stairs and in the street I was afraid I would succumb to fainting' [3, pp. 60-61]. It is thus not excluded that these recurrent impairments of consciousness represented complex partial seizures. Impairments of consciousness may be short or even absent in TLE and go unnoticed by the environment or the patient, who later notices only a 'general weakness' and 'mental perturbation' as noted by de Chirico [3]. 
ized by the inclusion of more elementary visual experiences into the graphical expressions of artists with migraine as shown by Fuller and Gale [1; fig. 2, 5] and Podoll and Robinson [10; fig. 3, 4, 11, 12]. We thus speculate that de Chirico's interictal behavioral manifestations, such as his heightened interest in moral and ethical issues, his philosophical preoccupation and belief in his precognitive abilities, might have influenced, together with the recurrent ictal sensory manifestations, the development of his presurrealist metaphysical art. Interestingly, de Chirico himself noticed a temporal coincidence of the initial development of his metaphysical art and the life period during which he most frequently suffered and described ictal and interictal epileptic manifestations. He wrote in 1910 that 'my health grew worse. Sometimes I painted small canvases. The Böcklin period [Arnold Böcklin, 1827-1901] had passed and I had begun to paint subjects in which I tried to express the strong and mysterious feeling I had discovered in the books of Nietzsche: the melancholy of beautiful autumn days, afternoons in Italian cities. It was the prelude to the squares of Italy painted a year later in Paris and then in Milan, in Florence and in Rome [...]' [3, p. 61].

Speculation about the relationship between neurological disease and the visual arts is an audacious and difficult task. Yet, several authors have described the influence of neurological disease on the artistic realizations in selected painters. Thus, it has been suggested that acute brain damage may lead to a change in style of an affected paint- er [11-14]. Other authors have investigated the influence of chronic neurological disease on artistic creativity and its influence on the style of a painter [1, 2, 8, 15, 16]. It has been suggested that paintings in these individuals may be modified or inspired by recurrent neurological symptoms $[1,2,15]$. Jaspers [15] stressed behavioral changes rather than behavioral disorders, emphasizing that disease-related behavior is not necessarily maladaptive or negative. TLE has been associated with artistic creativity in Fjodor Dostoievsky, Vincent van Gogh, and many others [8, 15]. In the case of Vincent van Gogh, the many letters to his brother, several medical reports, as well as data about his hospitalizations are available [16]. The relationship between van Gogh's epileptic disease and his current artistic creativity and style could thus be investigated more easily $[15,16]$ than in the case of Giorgio de Chirico, where such reports are not available. As in the previous studies of Fuller and Gale [1] and Podoll et al. [2], our analysis was based on self-reports from de Chirico's own literary work and some characteristics of his paintings. The fact that neither TLE nor migraine can be unquestionably excluded or confirmed for Giorgio de Chirico and that most patients suffering from TLE, or other chronic neurological illnesses, are not artists calls for further caution. In conclusion, although we cannot unambiguously posit that Giorgio de Chirico suffered from TLE, the present analysis suggests that some ictal and interictal features of TLE might have influenced his paintings as shown in other painters $[5,8,15]$.

\section{References}

1 Fuller GN, Gale MV: Migraine aura as artistic inspiration. BMJ 1988;297:1670-1672.

2 Podoll K, Robinson D, Nicola U: The migraine of Giorgio de Chirico. 1. History of illness. Neurol Psychiatr Brain Res 2001;9:139-156.

3 De Chirico G: The Memoirs of Giorgio de Chirico. London, Da Capo Press, 1994 (1st edition, Memorie della mia vita. Milan, Rizzoli, 1962).

4 De Chirico G: Hebdomeros. London, Exact Change, 1992 (1st edition, Hebdomeros, le peintre et son génie chez l'écrivain. Paris, Editions du Carrefour, 1929).

5 Schomer DS, O'Connor MG, Spiers P, Seeck M, Mesulam MM, Bear D: Temporal lobe epilepsy and behavior; in Mesulam MM (ed): Priniciples of Behavioral and Cognitive Neurology, ed 2. New York, Oxford University Press, 2000, pp 373-405.
6 Penfield W, Jasper H: Epilepsy and the Functional Anatomy of the Human Brain. London, JA Chrchill, 1954.

7 Waxman GS, Geschwind N: The interictal behavior syndrome of temporal lobe epilepsy. Arch Gen Psychiatry 1975:32:1580-1586.

8 Devinsky O: Interictal behavioral changes in epilepsy; in Devinsky O, Theodore WH (eds): Epilepsy and Behavior. New York, Wiley-Liss, 1991, pp 1-21.

9 Schmied W: De Chirico begegnet Apollinaire und malt sein Portrait; in de Chirico G: Reise ohne Ende. München, Prestel, 2001, pp 1937.

10 Podoll K, Robinson D: Visual migraine aura as a source of artistic inspiration in professional painters. Neurol Psychiatr Brain Res 2001:9: $81-94$
11 Jung R: Neuropsychologie und Neurophysiologie des Kontur- und Formsehens in Zeichnerei und Malerei; in Wieck HH (ed): Psychopathologie musischer Gestaltungen. Stuttgart, FK Schattauer, 1974, pp 27-88.

12 Gardner H: Art, Mind, and Brain. New York, Basic Books, 1983, pp 318-335.

13 Halligan PW, Marshall JC: The art of visual neglect. Lancet 1997;350:139-140.

14 Blanke O, Ortigue S, Landis T: Colour neglect in an artist. Lancet 2003;361:264.

15 Jaspers K: Strindberg und van Gogh. Versuch einer pathographischen Analyse. Berlin, Merve, 1998 (1st edition, 1922).

16 Gastaut H: La maladie de Vincent van Gogh envisagée à la lumière des conceptions nouvelles sur l'épilesie psychomotrice. Ann Méd Psychol 1956;114:196-238. 